Dejan Prša

\title{
Ljubimec z dolgim vratom. Motiv Lede z labodom v slovenski likovni umetnosti 20. stoletja
}

\author{
Ključne besede: labod, Leda, slovensko slikarstvo 20. stoletja, ikonografija, \\ zoofilija, interpretacije
}

\section{Uvod}

$\mathrm{S}$ tem besedilom se vračam $\mathrm{k}$ spominom $\mathrm{z}$ začetka študija na oddelku za umetnostno zgodovino, ko sem v proseminarski nalogi o Francetu Miheliču pri razbiranju slikarjevih antičnih motivov (Narcis, Dafne, Pan itn.) omenil tudi motive Lede, ker je ob istem času kot Mihelič v Moderni galeriji v Mednarodnem grafičnem likovnem centru razstavljala svoje mnogokrat iz antičnih mitov izhajajoče risbe slikarka Metka Krašovec. ${ }^{1}$ Zapis je kratek in risbe Krašovčeve povezuje z znamenitim razvojem motiva $\mathrm{v}$ evropskem slikarskem toku, ki sem ga takrat povzel po besedilu Gillesa Néreta iz knjige o erotiki v likovni umetnosti 20. stoletja: „Smo na jezeru, kjer labod išče svojo Ledo za skupno ljubezensko "razmerje«. (Ta motiv me asociira na Rubensovo, Veronesejevo, Dalijevo, Mühlejevo Ledo in Ledo Metke Krašovec, skratka, na neštete variante tega več kot zanimivega motiva.) « (Neret, 1993, 154-155; Prša, 2000, 24). Že ta drobna notica je zadosten dokaz, da gre v primeru Lede za enega najslavnejših in najpomembnejših antičnih oziroma mitoloških motivov, ki se mu je uspelo obdržati na površju vse do današnjih dni, in to ne le v veliki svetovni klasiki, ampak tudi v slovenski likovni umetnosti 20. stoletja, čeprav se o njem doslej v slovenski umetnostni zgodovini še nikoli ni pisalo. Obstajajo le natreseni drobci ob posameznih umetninah, ki nikoli niso doživeli napetih soočenj ali primerne sinteze.

K pomembnosti zgodbe o Ledi v osnovnem viru je zagotovo doprinesla povezanost z Zevsovimi (Jupitrovimi) ljubezenskimi podvigi, ${ }^{2}$ ki so jih radi uporabljali umetniki

$1 \quad$ V katalogu te slikarkine razstave v Ljubljani je Zoran Kržišnik prvič označil motiv Lede, ker te risbe ikonografsko nikoli niso bile natančno obdelane; čeprav so bile s strani številnih umetnostnih zgodovinarjev izvrstno interpretirane (Lev Menaše, Primož Lampič, Andrej Medved itd.), so se jim mnogi interpreti opusa Metke Krašovec nemalokrat celo izognili (1999, 6-8).

2 Ti so že od antičnih časov dalje velikokrat upodobljeni v skupinah. V oecusu hiše Vetijcev sta na primer upodobljena dva prizora Zevsovih ljubezenskih podvigov: Jupiter in Danaja ter Jupiter in Leda (Osvald, 1997, 48-49). Znane so Corregiove štiri slike iz cikla Jupitrove ljubezni: prva prikazuje Zevsovo polastitev Ganimeda s preobrazbo v orla, druga Lede s pomočjo laboda, tretja Danaje s pretvezo zlatega dežja in četrta Io s podobo oblaka. Ob vseh metamorfozah je Zevs zapeljal še Evropo 
vseh smeri in oblikovnih izrazov, ker so lahko pod krinko »ilustracije« mitološke zgodbe ob motivu dejansko sprostili erotične fantazije ne le naročniki in gledalci likovnih kompozicij, ampak tudi ustvarjalci sami. Čarovnije pri svojih skokih čez plot bi Zevsu zavidali vsi dandanašnji Casanove, ker se je pri osvajanju žensk posluževal preobrazb v različne ljudi, živali in stvari. V primeru zapeljevanja soproge špartanskega kralja Tindareja se je vztrajni ljubimec spremenil v belega laboda in svojo izbranko zalezoval pri kopanjih v reki Evroti. Ostalo pa ni le pri bežnih srečanjih, temveč so se posledice njunih telesnih zbližanj pokazale ob štirih jajcih, iz katerih so izšli Kastor, Poluks, Helena in Klitajmnestra (Hall, 1974, 191). Iz Lede izhajajo številne velike antične zgodbe, od Troje, Parisove sodbe do Helene in mnogih drugih, ki so vse pustile veliko sled v izoblikovanju najširšega možnega kulturnega ustvarjanja. ${ }^{3}$

Kljub antičnim oziroma profanim »koreninam « se je o Ledi pisalo tudi v sakralnem okolju. Leva Menašeja je Bergantova upodobitev Brezmadežne pri Uršulinkah v detajlu drže goloba sv. Duha na prsih spomnila na mitološko zgodbo: »Tudi motiv goloba, ki ga Marija drži pred prsmi, je nenavaden; če ga združimo z zamaknjeno Marijino držo, nas skoraj bolj spomni na motiv Lede kot pa na angelove besede 'Sveti Duh bo prišel nadte ...'; primerjava z mitološko temo pa seveda pri Bergantu ni na mestu « (1974, 15-16). Primerjava Lede z Marijo ni bila izpeljana iz nikakršnih provokativnih ali blasfemičnih vzgibov, ki bi piščevo misel približali neštetim napadom na podobo Marije, ki so bili v 20. stoletju vzpostavljeni v tuji in slovenski likovni umetnosti. Je pa Menašejeva primerjava obeh ptic povsem ustrezna, ker bi pri obeh lahko govorili o falični simboliki, a je ta pri labodu zaradi neposrednega motivnega konteksta vsekakor izrazitejša in so jo trdno vzpostavili že v antiki. Nič kaj iz trte zvite niso Mikuževe teze o povezavi med termini, $k i$ jih uporabljajo ornitologi, in poimenovanjem spolnih organov (Mikuž, 1995, 55-56). ${ }^{4}$ Odgovor za takšne razlage naj bi našli v psihoanalizi,

s prevzemom bikovega telesa in nimfo Antiopo z masko satira, kar je na freskah v dvorani gradu Brežice nazorno upodobil Frančišek Karel Remb (Novak, 1997, 79-80). Enako zanimivo je štiri najslavnejše Zevsove ljubezni naslikal Ferdinand Kulmer in si ob tem pustil malce več umetniške svobode. Na sliki Štirje Zevsovi obrazi (1987) je namreč vsem slavnim ljubimcem dodal lastnosti, s pomočjo katerih si jih je prilastil in tako Evropo upodobil kot ženski akt z bikovo glavo, Ledo kot akt $\mathrm{z}$ labodjim vratom, glavo in krili, Ganimeda kot moški akt $\mathrm{z}$ orlovskimi perutmi in glavo ter Danajo kot zlati dež. O Zevsovih ljubezenskih trofejah v svojem diplomskem delu o antičnih mitih v slovenski likovni umetnosti v poglavju Zeusove ljubezni piše tudi Alenka Simončič. V njem je veliko prostora namenjenega zgodbi o Evropi in Ganimedu (brez upoštevanja likovnih kompozicij slovenskih umetnikov!), Ledi pa sta posvečena le en stavek in omemba samo ene umetnine s tem motivom (Batičev kip Leda z labodom, 1973) (Simončič, 2000, 62-63).

3 Naj ob tem omenim le svežo Desertno kolekcijo (2009/10) Alana Hranitelja, narejeno za izložbo blagovnice Maxi; enemu od razstavljenih »bitij « v rumeni barvi je ime posodila prav Lepa Helena (Pelko, 2009, 25). Ali pa »ubeseditev« Parisove sodbe Jacoba Jordaensa iz ljubljanske Narodne galerije avtorja Borisa A. Novaka, ki dobro opisuje čare najlepše ženske na svetu, rojene iz labodove plemenitosti in lepote: »... jaz pa te bom nagradila z žensko, lepšo / od vseh žensk na zemlji. In utonil boš / v njeni koži iz dišečih, voljnih rož, / v očeh, kjer so zgoščeni žarki zvezde, / v laseh, kjer gnezdi bežni čas neveste ...« $(1997,30-32)$.

4 Za laboda je mogoče najti dober zgled v nemškem jeziku, kjer poimenovanje zanj (der Schwan) ustreza besedi za penis (der Schwanz). 
ker ta »meni, da dvigovati se $\mathrm{v}$ zrak in poleteti v nezavednem predstavlja erekcijo. K tej razlagi prispeva tudi asociacija na falično oblikovani vrat glave s kljunom pri pernatih živalih« (Mikuž, 1995, 55-56).

\section{I. del: llustracije mitološke zgodbe - od nežnega zapeljevanja do »bizarnega« seksa}

Pri motivih, ki v osnovi dosledno sledijo antičnemu viru, je mogoče govoriti o dveh skupinah upodobitev, ki izbirajo najbolj sočna trenutka v ljubezenskem razmerju med špartansko kraljico in dolgovratim pernatim ljubimcem: fazo zapeljevanja in njuno telesno združitev. Pravcato romantizirano »labodje jezero« je na sliki Leda (1912) ustvaril Gaetano Previati in v ospredje postavil nežen prizor s sedečo, do pasu golo kopalko, ki z desnico nič hudega sluteč krmi laboda, ki se ji je priliznjeno približal $\mathrm{z}$ veliko naklonjenostjo. Zvito dvorjenje pretkanega donhuana je odlično označil slikar Gustave Moreau, ki je leta 1875 naslikal več variant (Leda in labod, Leda, labod in kupido, Leda) z vznemirljivo mitološko snovjo: »Labodji kralj je svojo glavo položil poleg svoje izbranke, v vladarski drži uteleša v njej svojo belino in božanskost « (Oven, 2000, 20). Na sliki z ustreznim glasbenim naslovom Adagio, ki jo je leta 1903 ustvaril slikar Néstor Martín Fernández de la Torre, si par izkazuje še večjo obojestransko privlačnost, ker je božajoča roka na rečnem bregu ležeče Lede že zdrknila po privzdignjenem vratu med labodova krila, in zdi se, da bo ljubezenski prizor kljub vsebinski poanti naslova slike precej hitro doživel neizbežni vrhunec. Néstorjevo sliko je smiselno primerjati s kipcem Jamesa Pradiera, ker gre za povsem identično kompozicijo, in s sorodnimi umetninami številnih evropskih slikarjev, ${ }^{5}$ med katere je mogoče uvrstiti tudi vinjeto Matije Jame, ustvarjeno za prozno delo Ivana Cankarja (Ob zori, 1903), ki prikazuje rečni breg z golo žensko in ob njej v vodi dva laboda, izmed katerih se eden pomika proti prisotnemu aktu, ki ga, sklepajoč po drži rok, najverjetneje želi pobožati. Prizor je za vsebino Cankarjevih besedil preveč čutno naglašen, bi ga pa bilo možno povezati $\mathrm{z}$ motivom Lede, ker je bil motiv v času nastanka Jamove kompozicije še vedno zelo priljubljen kot odmev simbolističnih in secesijskih idealov, ki so velikokrat dajali prednost oblikovnim poudarkom pred vsebinskimi.

5 Čeprav so te likovne kompozicije nastale $\mathrm{v}$ časovnih zamikih izpod rok med seboj različnih si umetnikov in $\mathrm{v}$ različnih slogovnih odtenkih, se $\mathrm{v}$ vsebinskih poudarkih nemalokrat popolnoma izenačijo: Jean Thierry: Leda in labod (1717), François Boucher: Leda z labodom (1741), Peter Prosper Tillier: Leda in labod (1860), Maurice Ferrary: Leda z labodom (1898/1900), CA Holand: Leda z labodom (1910), Karl Weschke: Leda in labod (1986), Simon Posthuma: Leda z labodom (2003), Giovanni Rapiti: Leda z labodom (2008) itn. Posebej bi izpostavil Paula Cezanna (Leda $z$ labodom, 1880) in Theodorja Gericaulta (Leda z labodom, 1800): prvega zaradi igrivega detajla, ko labod zaljubljeno "grizlja «edino desnico, drugega pa zaradi dvoumne Ledine kretnje roke, ki laboda sicer odganja, a vseeno vzpostavlja telesni stik z njim in napoveduje pričakovani ljubezenski razplet. 


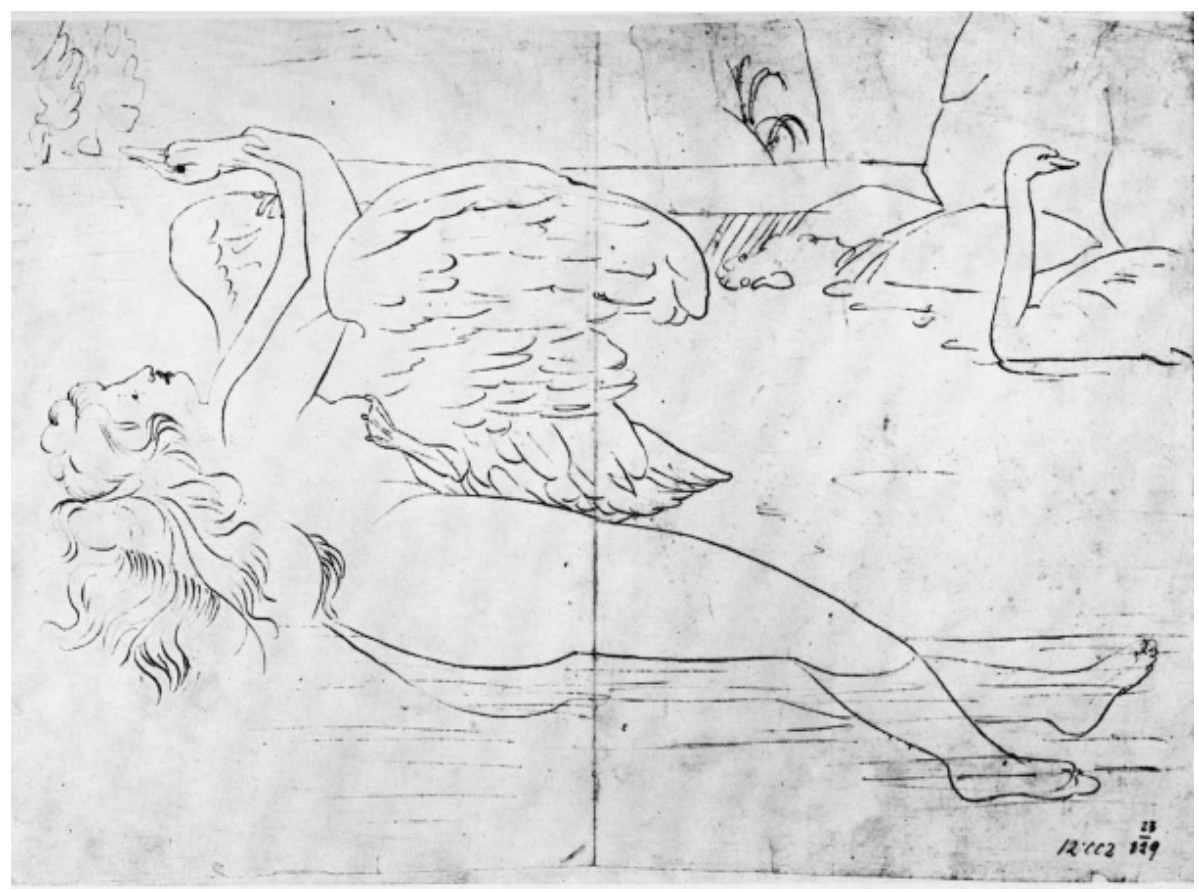

Slika 1: Jožef Tominc: Leda z labodom vir: Mostra di Guiseppe Tominz, 1966, 261

Čeprav si posamezni slikarji različnih smeri in izraznih načinov pri upodabljanju poljubnega motiva lahko izberejo zelo različne vsebinske in oblikovne poudarke, so se na primeru Lede vsi množično povezali v občudovanju telesne združitve ženskega akta z eno izmed najlepših ptic; temu mnenju pa je pri večini umetnin najbrž podleglo tudi (povečini moško) občinstvo. Najprimerneje je pregled tovrstnih kompozicij začeti z najstarejšo upodobitvijo, ki jo je v risbi s peresom ustvaril Jožef Tominc. Pri njegovi Ledi z labodom gre za precej klasično predstavitev mitološke zgodbe, in sicer $\mathrm{v}$ trenutku telesne spojitve. $\mathrm{V}$ jezeru ležeča Leda $\mathrm{z}$ razmršenimi dolgimi lasmi je $\mathrm{v}$ ekstazi nagnila glavo nazaj, $\mathrm{z}$ obema rokama strastno zagrabila neupogljivi labodji vrat in voljno sprejela nase celotno živalsko telo. Tominčevo ${ }^{6}$ kompozicijo so zaradi »čiste linije« brez kakršnega koli senčenja primerjali z ilustracijami Williama Blaka, čeprav bi jo bilo mogoče bolj upravičeno uvrstiti med prepoznavne značilnosti enako oblikovanih neoklasicističnih risb in njihovih naslednic v 20. stoletju (Picasso, pri nas Pirnat, Krašovec ...) (Jožef Tominc (1790-1866), 1967, 181). Druga slika, ki naj bi enako prikazovala vrhunec telesne združitve med Ledo in njenim živalskim ljubimcem, je

6 Tominc je labode vključeval tudi $\mathrm{v}$ druge slike $\mathrm{z}$ ljubezensko tematiko; na vazi s portreta Zaročencev je upodobljen motiv zaljubljencev »s kupidom v čolnu, v katerega sta vprežena laboda na jezeru (v Arkadiji?)«(Kos, 2002, 33-36). 
ohranjena le po ustnem izročilu in je nastala v ateljeju Antona Ažbeta. Ker gre v osnovi za eno izmed slikarjevih kompozicij z reševanjem problematike ženskega akta, na katere je bil Ažbe zelo ponosen, se ne gre čuditi, da je skrivnostna Leda z labodom (pred 1900) vseskozi vznemirjala zlasti raziskovalce, ki se radi posvečajo upodobitvam golih teles. Lev Menaše je v uvodnem besedilu razstave Akt na Slovenskem omenil Ažbetov poredni komentar (tole pa menda ne bo za Ljubljano), s katerim je ponosni slikar svojo drzno Ledo z labodom pokazal Miljutinu Zarniku (1999, n. p.). Enako zanimiv je v umetnostnozgodovinski literaturi zelo pogosto navedeni Zarnikov opis ${ }^{7}$ slike, ki priča o tem, da ga je upodobljeni prizor močno prevzel. Videl je namreč naslikano »krasno žensko bitje z razpuščenimi lasmi (ležeče na rečnem bregu) v srebrni jutranji svetlobi.« Tisti hip se mu je zazdelo, da je uzrl, »kako se dvigajo tiste bisernordeče prsi, h katerim se prislanja labod v neskončnem hrepenenju« (Zarnik, 1900, 167-168).

Čeprav izgubljena ${ }^{8}$ in le $\mathrm{v}$ nazornih spominih očaranega gledalca prepričljivo ohranjena, je Ažbetova slika v zbirki Ledinih upodobitev odličen primerek »erotične klasike«, ki mu lahko sledimo vse do umetnin Stojana Batiča in Jožeta Slaka-Đoke. Na obeh Batičevih kompozicijah, risbi iz cikla Satirijada (1974) in kipu Leda $z$ labodom (1973), je Leda na široko razkrečila noge in mednje sprejela pernatega ljubimca, ki se

7 Navajam nekaj primerov: Katarina Ambrozić, Anton Ažbe umetnik (1862-1905), 1988/89, 167-184, Petra Bizilj, Ženski akt prve slikarske generacije na Slovenskem, 2007, 20 in Beti Žerovc, Simbolizem $v$ slovenskem slikarstvu (1890-1918), 1997, 63. Problematična je obravnava Ažbetove slike pri Beti Žerovc, ker gre v njenem besedilu za ikonografsko posplošeni prikaz, ki se izmika objektivnim kriterijem. Ažbetova vznemirljiva Leda $z$ labodom je omenjena v poglavju o motiviki žensk in v posebnem poglavju o Ažbetu, ni pa je v razdelku Revitalizacija orienta in antike, kamor bi dejansko sodila (1997, 24-30, 44-46). Prav tako ni vzpostavljen primerjalni faktografski aparat s sočasnim evropskim slikarstvom, ki bi antični oziroma mitološki motiv ustrezno predstavil.

8 S skrivnostnim izginotjem se Ažbetova slika približuje Leonardovi Ledi (1508/15), ki jo je znotraj slikarjevega razvoja dobro označila Barbara Hochstetler Meyer (1990, 279-294), znani le prek zapisov in po številnih kopijah. Čeprav ji Vasari ne nameni pozornosti, jo omenjata Gaddiano in Lomazzo. Pri njej ne gre več za telesno združitev, ampak za čas po njem, ko so se iz jajc že izvalili vsi štirje slavni otroci. Leda in labod sta še zmeraj upodobljena kot par, desna perut ljubeče objema izbrankine boke (Geniji v umetnosti, 1990, 68). Pri Leonardu gre za kompozicijsko postavitev, ki jo (načeloma brez jajc z otroki) srečamo tudi pri drugih umetnikih. Prav pri njej je našel vzor Cesare da Sesto za svojo Ledo z labodom (1510), po njej se je zgledoval Pontormo za svojo kompozicijo Leda $z$ labodom (1527/30) in leta 1851 je po podobnih principih oblikoval Ledo z labodom že omenjeni James Pradier (Animaux d'art et d'histoire, 2000, 221-222). Iz Leonarda izhaja s sliko Leda atómica (1949) tudi Salvador Dali, ki je v mitološki zaljubljeni srečnici upodobil kar ženo Galo; ta tokrat sedi na nekakšnih pozlačenih podstavkih, ki kompozicijo bolj kot v pogansko okolje umeščajo $\mathrm{v}$ nedefinirano sakralno okolje. Močno spremenjen je tudi labod, ki izbranko še vedno objema okoli bokov, a je naslikan lebdeč v zraku in ga Leda še zmeraj objema in ljubeče gleda. Slikar si je tudi ta antični motiv, kot številne druge, prisvojil zaradi posebnega čustvenega razmerja, ker je v zgodbi o ljubimcih zagledal sebe v podobi laboda in ženo v Ledinem telesu, v rojenih dvojčkih pa simbol njunih »sorodnih duš«. Dali je spremenil tudi celotno ostalo okolje, ker sedaj prizor ne poteka več $\mathrm{v}$ »realistični« krajini s cvetlicami, ampak gre za nekakšno morsko »zaveso« $\mathrm{z}$ nekaj lebdečimi predmeti, med katerimi je tudi jajčna lupina kot drobna vez z Leonardovim slikarskim vzorom (Dali, 2004, 344-345). Renesančna kompozicija je vzpostavila trdno vez še z enim nadrealističnim umetnikom, Maksom Ernstom, ki je leta 1940 ustvaril Nevestino toaleto. Poza zelene ptičje figure na levi strani s puščico v desnici je odmev Leonardovega laboda, sedaj v odkriti podobi poudarjanja Zevsove falične simbolike. Slika je nastala ob slikarjevem proučevanju Freudovih idej (Hopkins, 1991, 237-244). 
v obeh primerih obnaša kot človeško bitje. Kot številne sorodne likovne kompozicije je tudi Batič sprejel podobo ljubezenskega para, ki se mora zliti v celoto po telesni enakosti, da bi se z njo v polnosti razživela strastna enakopravnost v spolnem odnosu. ${ }^{9}$ $\mathrm{V}$ sproščeni črtni risbi brez senčenja, ki obudi spomin na že predstavljeno Tominčevo Ledo $z$ labodom, se Batič, v strogem stranskem pogledu, približa Rubensovi ${ }^{10}$ (Leda $z$ labodom, 1598/1600) in Veronesejevi (Leda z labodom, 1580) upodobitvi mitološke zgodbe, pri kiparski umetnini pa se zazdi, kot bi pred nami v treh dimenzijah oživel čutni Corregiov prizor na rečnem bregu. ${ }^{11}$

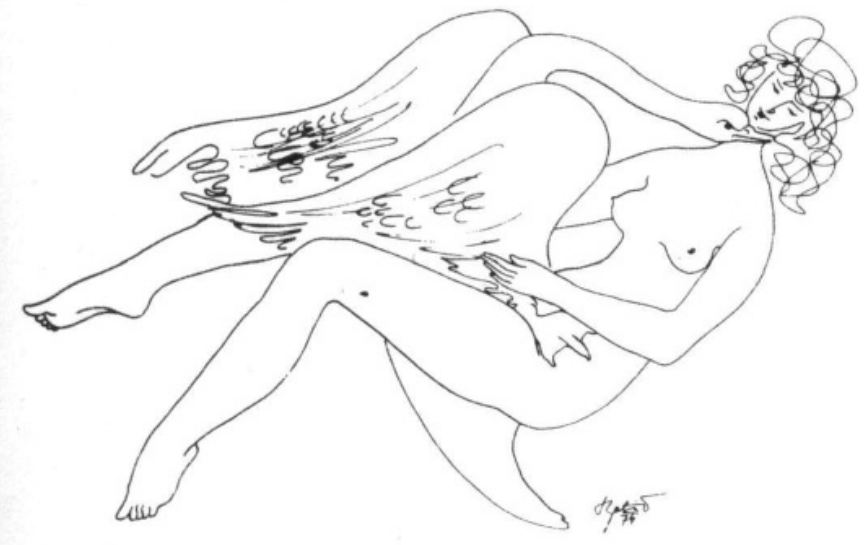

Slika 2: Stojan Batič: Leda z labodom, 1974

vir: Stojan Batič, 1977, 71

9 Nadnaravna velikost laboda je pogosta značilnost Ledinih motivov. V svoji Simboliki živali je Tine Germ na začetku poglavja o labodu reproduciral antični relief, ki kaže po človeško oblikovano ptico in stoječo varianto telesne združitve $(2006,105-108)$. Enake značilnosti lahko srečamo tudi pri preobrazbi Zevsa v orla, ko na kompozicijah z upodobitvami Ganimedove ugrabitve orel prevzema človeško velikost in človeške lastnosti. Vse to lahko opazujemo na Michelangelovi risbi Ugrabitev Ganimeda (1532), ki ptico in nemočno žrtev postavlja v vlogo homoseksualnega para. V neposredni upodobitvi se je orel v vlogi aktivnega ljubimca svojemu partnerju približal od zadaj. Kljub erotično naglašeni kompoziciji naj bi bil v njej »med drugim razviden vpliv neoplatonistične filozofije, $\mathrm{v}$ kateri Ganimed simbolizira dušo, ki jo božanska ljubezen v podobi orla dviga v nebo ...« (Germ, 2001, 21-29). Tudi motiv Lede se takšnim interpretacijam zelo približuje, ker naj bi bila še v baroku "atična (najverjetneje gre za pisno napako in je mišljeno antična, op. D. P.) legenda o Ledi in labodu interpretirana kot bitka med dobrim in zlim« (Mastnak, 1986, 38).

10 Slikar je navdih za svoji dve kompoziciji našel pri izgubljeni Michelangelovi sliki, ki se je v spominu ohranila po zaslugi bakroreza Cornelisa Bosa. Da bi poudaril čutnost naslikanega prizora oziroma erotične tone, je Rubens s svoje »kopije« odstranil na Bosovi kompoziciji prisotno jajce in rojena dvojčka (Widauer, Willinger, Willinger, 2004, 134-137).

11 V skorajda identičnem stranskem pogledu je na enem izmed krožnikov (Leda z labodom, 1961) motiv upodobil tokrat »realistični« Dali, vsekakor pa si zasluži omembo tudi slika Leda z Labodom (1966) Paula Wunderlicha, ki je v telesno ekstazo učinke pravljičnosti vnesel z uporabo izbrane barvne palete. Zelo me je presenetilo dejstvo, da sta v knjigi Antična mitologija Bronislave Aubelj ob vsej dobro dosegljivi ikonografski klasiki, ki jo obravnavam v tem poglavju, v razdelku o dosegljivih umetninah $\mathrm{z}$ Ledinim motivom v likovni umetnosti navedeni manj znani kompoziciji, ki ju podrobneje ne poznam: Bacchiacca: Leda z labodom, Rudolph Tegner: Leda $z$ labodom $(2006,75)$. 
Če se je Batič dosledno vpel v upodabljajoči kliše, ki mu ne sledimo le do baroka in renesanse, ampak dejansko daleč nazaj v antiko, ${ }^{12}$ je Jože Slak-Đoka s sliko Leda (1983) razrahljal vez s premočrtno potekajočo in globoko vkoreninjeno tradicijo. Oblikovnemu »naturalizmu« se je pri odslikavi ljubezenske sreče slikar spretno izognil in spolni akt preoblikoval v fluidno mešanico človeških in ptičjih telesnih delov v nežnih rožnatih barvnih tonih. ${ }^{13}$ Slikar je kompozicijo koncipiral $\mathrm{z}$ uspešnim odmikom $\mathrm{v}$ abstrahiranje, kar je pri erotičnih tematikah v likovni umetnosti preizkušen fenomen, ${ }^{14}$ in v duhu svojih metamorfoznih barvitih rezljank. Dva velika slikarja, ki sta vse to pri motivu Lede z labodom uresničila že dolgo pred njim, mu odrekata posebno izvirnost. Max Ernst je na Ledi z labodom (1927) pustil le bežen obris dveh fantastičnih bitij, ki se $\mathrm{v}$ čutnih zasukih razkrajata ali sestavljata iz človeških in ptičjih telesnih delov ter stapljata $\mathrm{v}$ dekorativno zastavljeno poploščeno slikovno površino. Pri naslednji kompoziciji, Leda (1961), teles obeh protagonistov ni več mogoče zaznati, ker je Cy Twombly pustil prosto pot energičnim slikarskim gestam, ustvarjajočim sugestivne znake, ki kažejo na »horror vacui« in za slikarja značilen naslon na Jacksona Pollocka in Willema de Kooninga (Anfam, 2008, 701-702). Kot pri obdelavah drugih antičnih tematik (na primer: Hero in Leander, 1981/84), je Twombly z artikuliranim likovnim jezikom in izpuščanjem realističnih detajlov, podobno kot Đoka, tu dosegel čisti prikaz prisotnih ljubezenskih strasti in čustev (Anfam, 2008, 701-702).

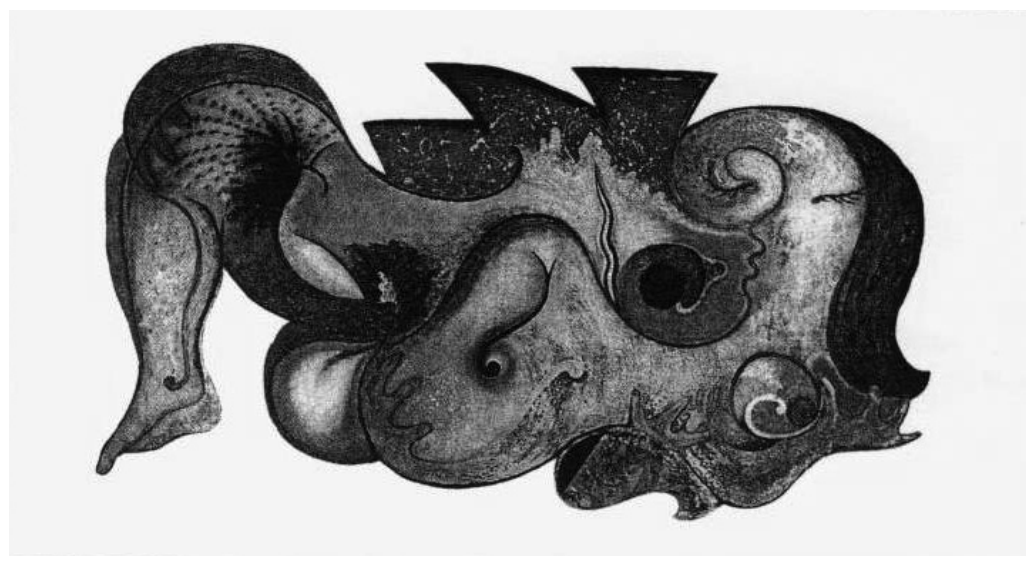

Slika 3: Jože Slak-Đoka: Leda, 1983 vir: Sedej, 1993, 27

12 Presenetljivo trdno vez renesančnih in baročnih upodobitev $\mathrm{z}$ antičnimi deli v kompozicijskih in vsebinskih poudarkih, čeprav gre za velike časovne razmake in slogovno različnost, je dokazala Elfriede R. Knauer in obenem s svojim člankom sestavila obsežen motivni pregled (1969, 5-35).

13 Ivan Sedej, ki je Đokovo kompozicijo reproduciral v uvodnem besedilu svoje knjige Ljubezen $v$ stotih slikah, je ob njej zapisal, da gre za »ljubezen med mitologijo in vsakdanjostjo $(1993,27)$.

14 Za predstavitev sorodnih del priporočam: Touch me/Abstract eroticism (1996). 


\section{II. del: Vsebinski in oblikovni presežki v okolju zasebnih mitologii}

\section{Spreminjanje osnovnih značilnosti antičnega vira}

Kljub temu, da antična snov Lede nikjer ne spreminja v labodje telo, ${ }^{15}$ si je veliko umetnikov želelo svobodno preoblikovati njen telesni videz. V vseh treh slikah (Leda, 1983, Štirje Zevsovi obrazi, 1987, Leda z vodeno kobilo, 1986) z motivom Lede je Ferdinand Kulmer gracilnim ženskim aktom dodal posebej krhki videz s ptičjimi krili, vratom in glavo. Pri tem se je zavedal, da se je v vsebinskem in oblikovnem smislu odmaknil od ustaljenih upodobitvenih vzorcev. Nanovo napisane antične zgodbe je treba razumeti v samosvojih kontekstih, ki se v celoti vežejo na avtorsko izraznost samega umetnika. ${ }^{16}$

$S$ podobnimi interpolacijami v grško zgodbo se srečamo tudi pri slikarju Jožetu Megliču, ki je motivu Lede $\mathrm{z}$ labodom posvetil precejšen del svojega slikarskega opusa $\mathrm{v}$ daljšem časovnem razdobju. Motiv ga je zaposloval vse od leta 1975 do leta 2000 in se je v tem času korenito spreminjal. Prve kompozicije (Leda, 1975, Brez naslova, Leda, 1975) so s spremembo Lede v ptico primerljive s pravljično fantastičnim Kulmerjem, a jih je Meglič na vsebinski ravni zaznamoval z drznimi erotičnimi konotacijami, značilnimi za svoj celotni slikarski opus, ki pa se docela izmikajo stereotipom, predstavljenim v prvem poglavju članka. Megličeva Leda je »dvospolno bitje« in se s priraščenim labodjim vratom, »ki spominja na falus«, sama oplaja ali le samozadovoljuje (Globočnik, 2009, 30-31). Če gre v resnici le za avtoerotiko, bi bilo mogoče te slike uvrstiti v Megličevo značilno erotično rdečo nit, ki se vzpostavi z vrsto erotičnih kompozicij. Te nemalokrat spreminjajo telesa ljubimcev $\mathrm{v}$ fantastična hibridna bitja in predstavljajo različne poglede na temo samozadovoljevanja. ${ }^{17}$

15 Do spremembe ženskega akta v ptico naj bi v grškem mitu dejansko prišlo, a to nikakor ne $\mathrm{v}$ zvezi z labodom. Nekateri so namreč prepričani, »da se je Zevs spremenil v laboda, da bi prišel do Lede, šele potem /.../, ko se je ta spremenila v gos, da bi mu ušla. Videli smo, da je gos ena izmed avatarjev laboda v njegovem lunarnem in ženskem pomenu " (Chevalier, 1995, 301-302). V laboda so se v grški mitologiji načeloma spreminjale druge osebe, poznana je sprememba Orfejeve duše v laboda in nesrečna preobrazba Faetonovega prijatelja Kiknosa: »Veliki rimski pesnik pravi, da labod (gr. kýknos) dolguje svoje ime ligurijskemu knezu in slovitemu pevcu Kiknosu, prijatelju nesrečnega Faetona, ki si je drznil voziti sončevo zaprego svojega očeta Helija in ga je Zevs za kazen udaril s strelo. Kiknos, ki ni mogel preboleti smrti svojega ljubega, je tako dolgo jokal na bregu reke, v katero je strmoglavil Faeton, dokler se ni spremenil v laboda, ki s tožečim petjem oznanja svojo bolečino." (Germ, 2006, 105-108) V izdaji Ovidovih Metamorfoz pri Kondorju lahko občudujemo bakrorez Mathäusa Meriana, ki je bil izdelan kot naslovni list k drugi knjigi Metamorfoz $(1977,61)$.

16 To je ob Kulmerjevi razstavi v Piranu leta 1989 poudarjal že Zvonko Maković: »Ti naslovi jasno opozarjajo na mitološka izhodišča, vendar pa so prizori na slikah dvosmiselni. Kulmerjeva Leda, kakor tudi Zeus, Ganimed, Pegaz so hibridna bitja, ki onemogočajo ikonografsko dešifriranje prizorov. Te načrtno narejene nejasnosti Kulmer v ikonografskem programu dopolnjuje in še povečuje z uporabo barve, načinom slikanja ...« (Maković, 1989, n. p.).

17 To potrjujejo naslednje Megličeve kompozicije: Sama (1974), Porno 80 (1980), V praproti (1975), Noč (1986), Porno 4 (1986), Orgazem (1989), Erotična krajina (1986) itn. 


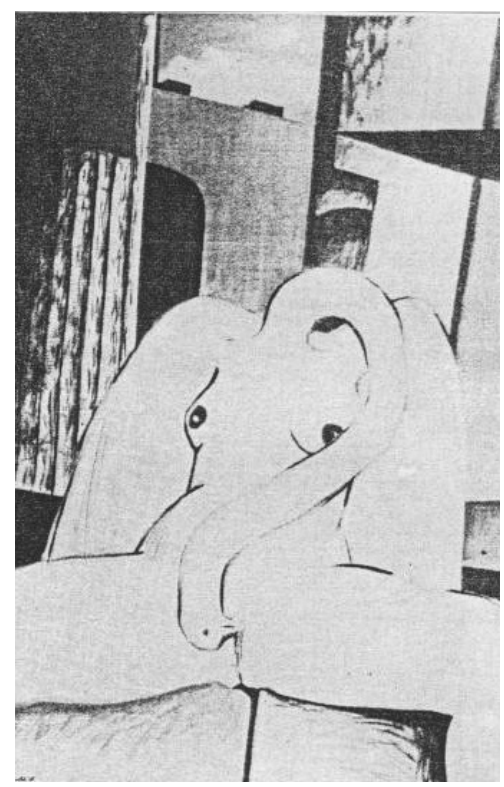

Slika 4: Jože Meglič, Leda, 1975

vir: Razstava DSLU ob 30. letnici osvoboditve, 1975, 81

Prvo fazo je slikar presegel $\mathrm{v}$ devetdesetih letih, ko je $\mathrm{z}$ novimi raziskovanji »uporabil kubistično izkušnjo razbijanja in ponovnega sestavljanja slikarske ploskve, ki jo je dopolnil s koščki aluminijaste folije«, razvoj v to smer pa nakazal že pri starejši sliki Leda 2 (1983), ko je ženski akt in ptico spremenil v fantastično tvorbo, ki spomni zlasti na nadrealistične domišljijske konstrukcije (Globočnik, 2009, 30-31). Po kompoziciji Ledina igra $z$ ogledali (1995), ki že naznanja vidne vsebinske odmike, ker iz naslikane pripovedi začno izginjati poprej zelo izraziti erotični toni, je Meglič utišal tudi prepoznavnost upodobljenih akterjev. Nova vsebina je "poetična«, labod se iz erotičnega simbola prelevi v »atribut glasbe«. Novonastale slikarske kompozicije so označili kot »fantazijske pejsaže«, z njimi pa naj bi slikar »v domišljijski pejsažni organizem povezal mehko zaobljene oblike stiliziranih ptic, ki se prelivajo ena $\mathrm{v}$ drugo « (Globočnik, 2009, 30-31). Slikarjeve slike te faze (Umirajoča Leda, 1999/2000, Temna Leda, 1999, Leda $z$ ogledali 2, 1999, Leda z ranjenim srcem, 2000, Hommage za Berto Bojetu, 2000 ...) so primerljive z Jakšetovo slavno Belo čredo ${ }^{18}$ (1999), nastalo nekako $\mathrm{v}$ istem času kot Megličevi najuspešnejši primerki zadnje faze obdelovanja Ledine zgodbe, ki segajo vse do leta slikarjeve smrti (2006), čeprav o kakršnem koli medsebojnem vplivu najbrž zelo težko govorimo.

18 Za razliko od Megličevih kompozicij gre pri Jakšetu za različne živali, spojene $\mathrm{v}$ fluidno belo tkivo. Belo čredo sem v že omenjeni proseminarski nalogi interpretiral s pomočjo Kovičevega Psalma, ker je name naredila velik vtis, ko je bila ob prehodu leta 1999 v leto 2000 razstavljena na razstavi z naslovom Ne t'č ne m'š v galeriji Equrna. 
Da nekatere likovne umetnine vzbudijo pri dobro razgledanih gledalcih aluzije na slavne motive, čeprav takšnih zbliževanj avtorji slik in kipov niso imeli namena vzpostavljati, je povsem upravičeno interpretativno dejanje; tudi sam sem že prej ob Jamovi vinjeti s prizorom gole žene ob jezeru $\mathrm{z}$ labodoma potegnil vzporednico $\mathrm{z}$ Ledino zgodbo. ${ }^{19}$ Prepletanje bom nadaljeval ob fotografiji iz cikla Moški akt (2002) Stojana Femca, ki prav tako prikazuje akt (tokrat moški!) v vodi in ob njem plavajočega laboda. Enako izvirno bi nas na mitološki vir spomnila slika Léona Frédérica Jezero, speča voda (1897/98), ker bi lahko v nerealno učinkujočem kolažu človeških spečih teles (žensk in otrok), nad katerim se razprostira jata spokojnih labodov, uzrli namige o Ledini prisotnosti ali bi se nam morda zdelo potrebno sliko razlagati $\mathrm{v}$ tem poznanem kontekstu, česar bi se lotili zato, da bi si neznano vsebino nekoliko približali in udomačili. Motiv Lede z labodom bi lahko priklicali na plan pri ljubezenski pesmi Tvoje telo Antona Dolenca, ker bi nas k temu zavedli pomenljivi slikarjevi verzi: »Tvoje telo, ki ga daješ v slovo, / ki joče in ljubi in hoče za vselej / imeti minute, ki v prazno gredo ... / Pojte, labodi, v viharje morja, / pojte v gorovje, upornosti skal, / pojte v pozabo svoj večni koral ...« $(2009,24)$

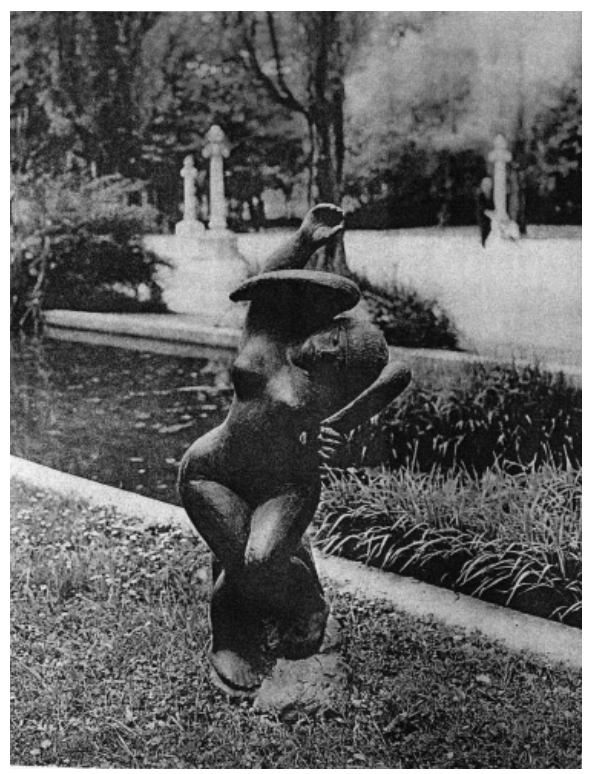

Slika 5: Peter Loboda, Umirajoči labod, 1936

vir: Peter Loboda (1894-1952), 1966, n. p.

19 Vinjeto je reproducirala Žerovčeva v diplomskem delu, a o njej ni pisala. Ker je povzela Juterškovo tezo, ki namesto Miljutina Zarnika v vlogo skrivnostnega Artifexa postavlja Matija Jamo, bi bilo s strani avtorice besedila smiselno namigniti, da je Jamo mogoče označiti za Ažbetovega obiskovalca $\mathrm{v}$ ateljeju takrat, ko je tudi vinjetni prizor mogoče opredeliti za motiv Lede z labodom (1997, 28, 107-109). Jama bi namreč navdih za svojo čutno kompozicijo lahko dobil prav prek Ažbetovega skrivnostno izginulega akta. 
Tudi ob precej znani kiparski skulpturi Petra Lobode Umirajoči labod (1936) je mogoče napeljati na zgodbo o Ledi. K temu nas ne prisili le umetnikov priimek, ampak oblikovanje ženskega akta z labodjimi krili, ki se s tem približuje ravnokar obravnavanim Megličevim in Kulmerjevim kompozicijam. Vsebina Lobodovega kipa ni bila nikoli problematizirana oziroma se o njem ni nikdar obsežneje pisalo. Vselej je bila v ospredje potisnjena njegova oblikovna plat. O njej je v zvezi s problematiko akta pisal Lev Menaše in hvalil predvsem njeno »baročnost«: »Umirajoči labod iz leta 1936 pa je načeloma sicer "mediteransko" popreproščena, a dejansko baročna in tudi v značilno baročni ekstazi zvijajoča se figura.«(2000, n. p.) Morda je povezava z mitološko zgodbo pri Lobodi pretirana in bi vsebino lahko potisnili v območje poezije ali literature, a nikakor ne zaradi tega, ker se je ekspresionistična revija imenovala Trije labodje. ${ }^{20}$ Mišljena je predvsem povezava z labodom samim, ker je imel ta na področju poezije in literature prav posebno pozicijo. ${ }^{21}$ Lobodov hibrid med človeško figuro in labodom se v slovenski likovni umetnosti ponovi na risbi Nosonja (1986) Gorana Horvata. Je pa spreminjanje človeških teles v živalska v slovenski umetnosti vseskozi prisotno in ne temelji vedno na antičnih virih. Če je Boris Kobe ljudi spreminjal v kentavre, Izidor Urbančič v sirene in Maksim Sedej ml. v metulje, je Jakob Savinšek razvil sorodno metamorfozo med človeškim telesom in pernatimi živalmi. ${ }^{22}$

Zamenjave živijo tudi v sakralnem okolju. Že navedeni Menašejev hoteni prenos mitoloških značilnosti Ledinega motiva v sakralno okolje je dobil »nasledstvo" s sliko Hommages a Dali: Leda in labod, ki jo je leta 2007 naslikal Samo Kralj. Naslov sam pove, da lahko v njej pričakujemo hotene reminiscence na Dalijevo slikarstvo. To navezo je Samo Kralj izpeljal z zgledovanjem pri Dalijevi sliki Kristus Janeza od Križa (1951), ker je po njej dobesedno povzel pokrajino z lebdečim križem; Kristusa je odstranil iz nje in namesto njega $v$ horizontalni legi naslikal lebdeči ženski akt (Ledo!), ki mu je z belo draperijo v celoti prekril obraz. Zaradi tega detajla nas slika spomni na slikarske akte Rudija Španzla, zanimiva pa je tudi postavitev laboda, ki ga komajda opazimo, ker je kot majhen "ptiček « upodobljen ob Ledinih nogah in je prej podoben golobu sv. Duha ali značilnim Kraljevim krhkim flamingom z drugih slikarjevih kompozicij. Kraljeva slika želi ustvariti nadrealno vzdušje in je trdno vpeta v izoblikovane značilnosti njegovega slikarskega ustvarjanja: „Glasba in upodabljajoča umetnost sta Kraljev način življenja, stanje njegovega duha, zato v iskanju spoznanja in razodetja, ki ga v realnem, izkustvenem svetu ne najde, večkrat zaide na področje transcendentalnega,

20 Za prvo številko leta 1920 je naslovnico izdelal France Kralj in v detajlu ukrivljenega labodjega vratu vse tri umetnosti, ki so jih umetniki ekspresionizma najvišje častili (glasba, slikarstvo, poezija), združil z njihovimi atributi (paleta s čopičem, lira in knjiga poezij).

21 Med številnimi pesniki, ki so se jim v verzih »ugnezdili« labodi s širokim spektrom vsebinskih sporočil in pomenov, velja izpostaviti zlasti Otona Župančiča in njegove verze v pesmi Vihar: »Na škripajoči verandi smo stali, / za roké se z dekleti držali, / bledi gledali zmédeni kraj: / le labod, samotni ptič, / mirno prevaža, kot da ni nič, / po valovih svoj beli sijaj.« (Župančič, 2000, 29) 
nadčutnega, nadnaravnega.«(Matijevič, 2007, 5-6) Naj omenim, da sem se na motiv Lede $\mathrm{z}$ labodom spomnil23 ob upodobitvi svetega Martina Janeza Andreja Straussa v postavitvi tolste gosi ob svetnika, ki bi jo marsikateri površni gledalec slike pomotoma zamenjal z labodom, a je gos tu prisotna »kot razpoznavno znamenje«, čeprav "se ne meni za svetost dogodka, ampak je stegnila dolgi vrat in šavsnila proti nevidni nevarnosti v naravi« (Komelj, 2008, 144-145).

\section{Drugačno »branje« zgodbe o Ledi}

S predstavitvijo nekaterih umetnikov, ki so se posvečali obravnavanemu motivu, je možno govoriti o globlji refleksiji motiva, ki prinaša drugačen pogled na ljubezen med Ledo in labodom. Umetnine, ki jih bom obravnaval v nadaljevanju, se izmikajo doslej opredeljenim vsebinskim sporočilom in omogočajo izoblikovanje novih vsebinskih konotacij. Z njimi je mogoče vzpostaviti problematike reševanja nekaterih gledalčevih odklonilnih zadržkov, ki se lahko pojavijo ob Ledini zgodbi.

Že ob nekaterih poprej obravnavanih umetnikih sem izpostavil preobrazbe človeka v žival, ki bi se lahko prenekateremu gledalcu zazdele moteče in bi ga odvrnile od opazovanja likovne umetnine. $\mathrm{Na}$ izrazitem primerku metamorfoze človeka $\mathrm{v}$ žival v sodobni umetnosti si je mogoče ogledati različne odzive, ki jih takšni projekti povzročijo. Pasje performanse sodobnega "Zevsa u umetnika Olega Kulika je občinstvo sprejemalo različno; enim so se zdeli smešni in zabavni, drugi so se nanje precej negativno odzvali, ker se jim je zazdelo, da je šlo umetnikovo obnašanje v prostoru umetnosti daleč čez rob. Če je ovohavanje obiskovalcev galerije še sprejemljivo, je grizenje otrok po "pasje« vendarle nekaj povsem neprimernega in je zato klicanje policije edina možnost, ki se človeku pri tem porodi. Malokdo je pri tem pomislil, da imajo ti performansi globljo poanto, ker naj bi bili "nadaljevanje zgodbe Pasje srce Bulgakova, v kateri psa z operacijo spremenijo v človeka, nakar se po zaslugi svojih živalskih nagonov zelo dobro znajde v sovjetski družbi dvajsetih let prejšnjega stoletja« (Stallabrass, 2007, 43-47). Z njimi je problematiziran odnos med človekom in živaljo, ki je v 20. stoletju v likovni umetnosti postal veliko bolj izpostavljen kot poprej. ${ }^{24}$

23 Podobno se je pripetilo Igorju Kranjcu ob »kultni« sliki Franceta Kralja Moja žena $z$ beneškim ozadjem, ker je v njej prepoznal prepričljive aluzije antične ljubezenske igre med Ledo in labodom. Pri spreminjanju Kraljeve kopalke z belo brisačo v zaljubljeni par se je oprl na Leonardovo Ledo: »V brisači se skriva kriptomorfna podoba laboda in Kraljevo ženo nekako spravlja v odnos do Leonardove Lede. Ta, danes izgubljena umetnina, je bila eden prvih renesančnih aktov, ki je aludiral na žensko plodnost; s tem je Leonardo postavil žensko seksualnost v aktivno vlogo. Kralj je mitološki kontekst transformiral, ne da bi umiril tresljaje erotične privlačnosti ženskega telesa. Žena $\mathrm{z}$ beneškim ozadjem predstavlja /.../ aktivni, falični princip.« (1993, 85-86) (Kranjc je med stranjo 84 in $85 \mathrm{v}$ magistrskem delu reproduciral dve Leonardovi študiji za končno sliko.)

24 Morda bi o zapleteni preobrazbi umetnika v psa vedela več povedati Renata Salecl, ki je o Kuliku napisala odličen članek $(2000,111-121)$. 
Umetniki so prevpraševali človeško premoč nad čistim živalskim svetom, ki se ne kaže le v trenutkih ubijanja ${ }^{25}$ ali na krožniku za kosilo, ampak na mnogih drugih mestih. Za zelo sporno področje se izkaže problematika zoofilije oziroma spolnosti z živalmi, ki je dejansko odraz odkritega nasilja nad živalmi in bi jo bilo treba globlje reflektirati in opredeliti. Tudi umetniki jo na svojih slikah prepogosto goreče zagovarjajo, ker naj bi bila $\mathrm{v}$ likovni umetnosti prisotna vse od samih začetkov in je $\mathrm{v}$ samem ustroju civilizacije prisotna še danes. Kljub dejstvu, da rušenju vseh vrst tabujev željnim potrošnikom nič kaj težko dostopni spletni meniji zlahka postrežejo s prizori spolnih aktov med človekom in najrazličnejšimi živalmi, popreproščeni izgovori ne bi smeli biti zadosten razlog za njihovo nekritično upodabljanje.

Motivi, ki prikazujejo neposredno upodabljanje seksualnosti med ženskim aktom in labodom, in veliko takšnih sem doslej že opisal, so dejansko etično sporni $\mathrm{v}$ trenutkih, ko ne gre za kakršne koli načrtne kritične pripombe ali premisleke $\mathrm{s}$ strani avtorjev umetnin, zavajajočih tudi do gledalcev, ker bi si jih lahko ti po svoje docela napačno razlagali. Med vso množico motivov z Ledino zgodbo so me najbolj pritegnili avtorji, ki so se na svojih likovnih kompozicijah odvrnili od neposrednega upodabljanja erotičnega akta ter znani vir vsebinsko in oblikovno docela svobodno preoblikovali v skladu z značilnimi izvirnimi avtopoetikami ali pa ga pospremili z drugačnimi likovnimi komentarji.

Med slovenskimi umetniki, ki so se posebej izrazito posvečali upodabljanju "opolzkih scen« med človekom in živaljo, izstopa umetnica Metka Krašovec. Slikarka je v drugem ustvarjalnem obdobju z množico risb zaobjela celo plejado ikonografskega repertoarja motivov, ki nemalokrat namigujejo na telesne združitve človeka in živali. Ne glede na trditve nekaterih slikarkinih interpretov, ki so prepričani, da teh risb ni mogoče natančneje ikonografsko klasificirati, vendarle premnogi detajli zgovorno pričajo, da se umetnica s svojimi kompozicijami uvršča $\mathrm{v}$ poznani in prekaljeni tok svetovne likovne umetnosti. ${ }^{26}$ Morda te risbe zaradi neposrednosti upodobljenih prizorov, ki so nemalokrat precej erotični, velika

25 Nemalokrat se je živali ubijalo tudi v umetniških projektih. Nad neprimernostjo ubijanja telička v ŠKUC-u, ki ga je leta 1998 (projekt Where is the line ... tukaj, tukaj) uprizoril Franc Purg, se je zgražal Miklavž Komelj in pisal, da je bila z njim »uresničena le pošastna bebava anemičnost samega ubijanja, ki je do skrajnosti afirmirala prenažrto brezbrižnost« (Komelj, 2002, 118-125). Komeljeva obtožba je v tem primeru zelo iskrena, ker je pisec že poprej velikokrat obsojal človekovo nehumanost in njegovo izživljanje nad nedolžnimi živalskimi bitji; med drugim tudi ob Eisensteinovi "Stavki, kjer je pokol stavkajoče množice metaforično ponazorjen s prizori ubijanja goveda. Posneta je resnična snov; še živemu govedu iz prerezanega vrati (najverjetneje gre za pisno napako in je mišljeno vratu, op. D. P.) lije kri, pri tem pa mu postopoma ugašajo oči« (Komelj, 1999, 59-62).

26 Tovrstne argumente je mogoče izpeljevati iz prepričanja, da se je Krašovčeva pri izoblikovanju kompozicij dokazljivo oprla na detajle nekaterih znanih tujih umetnikov (zlasti David Hockney in slikarji italijanske transavantgarde: Francesco Clemente, Enzo Cucchi, Sandro Chia itd., kar se tiče zoofilije pa tudi na sorodna dela s to tematiko v zvezi z različnimi živalmi: srna, tiger ...); te risbe niti niso posebej izvirne, za kakršne jih imajo njihovi najzvestejši interpreti (zlasti Tomaž Brejc in Andrej Medved). 
večina umetnostnih zgodovinarjev $\mathrm{v}$ pregledih slikarkinega dela v celoti izpušča ali z njimi opravi precej na hitro. Krašovčeva je zasebni pogled na Ledino zgodbo ob omenjenem ciklu upodabljala še na sočasnih akrilih večjih dimenzij in v risbah, nastalih $\mathrm{v}$ devetdesetih letih.

slika 6: Metka Krašovec: Brez naslova, 1997 vir: Metka Krašovec, 1999, 48

Iz množice kompozicij (Piramida, 1983, Zeleno, 1983, Aydé (Hayden), 1985/86, Brez naslova, 1986, Dotik, 1986 itn.), ki jih je zaradi umanjkanja avtoričine lastne identifikacije (ta bi bila lahko izvedena v prvi vrsti na samih naslovih umetnin) mogoče motivu Lede samo pripisati in so dokončni sklepi zagotovo izključeni, bom izbral le tri slikarkine kompozicije in jih natančneje analiziral. Kot sem zapisal na začetku članka, je Zoran Kržišnik edini ob umetničinih risbah izpostavil navezo na antično zgodbo: »Pogost je Ledin motiv, zveza ženske in laboda, iz katere sta se rodila deviška Diana in začetnik umetnosti, Apolon, ki je poseben ustvarjalkin ljubljenec in vzor « (1999, 6-8). ${ }^{27}$ Čeprav so na kompozicijah slikarke Metke Krašovec mnogi jasno razbrali problematiko telesne združitve med človekom in živaljo, jih ta ni motila, ampak so jo skušali na vse mogoče načine zagovarjati in sprejeti. Izgovore za njen obstoj so našli v odmevih starih sredozemskih kultur, poskušali so jo opravičiti z odmikom v svet literature, poezije, ${ }^{28}$ filozofije ... Slogovno docela uvrstljive v postmoderni izziv

27 Opozarjam, da Kržišnikov zapis ne sledi faktografskim dejstvom.

28 Kot mojstrski razlagalec risb slikarkine druge faze se je izkazal Andrej Medved, ki jih je natančno označeval kmalu po nastanku leta 1983, ko je pisal: "To združenje v Krašovčinih slikah (kljub sodomiji) ni kruto in blasfemično, perverzno. V njem ni nobene zlobe in trpljenja ter sadovske uničevalne sle, ki zaustavlja in duši telesno srečo. /.../ Ljubezenske združitve torej ni, ker slika 
predstavljajo tisto »Zamaknjenje, ki živi v duši, rojeni iz večnega morja kot domotožno strmenje k popolnosti« (Kržišnik, 1999, 6-8; Komelj, 1995, n. p.). Izbrane tri slikarkine kompozicije (Dotik, 1986, Brez naslova, 1986, in Brez naslova, 1997) z Ledinim motivom bodo potrdile tezo, da se razlaga združitve med človekom in živaljo skriva v detajlih risb samih, v njih pa se tudi razodeva pomembno slikarkino zasebno razumevanje antičnega vira. Pri Dotiku se zdi, da bo razlaga kompozicije precej enostavna, ker sta ženski akt in lebdeči labod vendarle dokaj realistično upodobljena. Kljub naslovu je jasno, da do dotika ne bo prišlo, ker je gola ženska samovšečno sklonila roki nad glavo in labodu zaenkrat obrnila hrbet. Risba zbuja upravičene aluzije na kompozicijo Hrepenenje (1972) Staneta Jagodiča; njegova skrivnostna ženska, ki se je z rokami trdno oklenila letečega laboda, bi lahko predstavljala morebitno nadaljevanje prizora Krašovčeve, a smo vseeno še zelo daleč od kakršne koli telesne združitve (Stane Jagodič, 2008, n. p.). Zaenkrat obstaja samo prostor čiste lepote in nežnih čustev. Tako je tudi pri nenavadno krhko učinkujoči risbi Brez naslova (1997); ta je v dobesednem pomenu prikaz tiste poetične melanholije, ki jo je v umetničinih risbah našel Boštjan Soklič (1999, 9-11). Kompozicijska postavitev je Dotiku pravzaprav zelo sorodna, a gre tokrat za domišljijsko preoblikovanje obeh protagonistov mitološke zgodbe in izraziti odmik v zasebno slikarkino mitologijo, ki je sanjska, nežna, lirizirana in ženska. Leda se je spremenila $\mathrm{v}$ nekakšno človeško pokrajino, obdano $\mathrm{z}$ vodo, iz labodovih kril in trupa se izvija moška postava. Moške roke se približujejo ležečemu ženskemu aktu in zdi se, da mu bodo v predelu vratu hrepeneče razprle telo in se ugnezdile v njegovo dušo. Podoba razkriva »neoplatonizem « in v barvni izbranosti »občutek nadčutne resničnosti« (Mastnak, 1999, 12-20; Grobler, 2010, n. p.). Tretja izbrana risba Brez naslova (1986) sledi podobnim vsebinskim poudarkom, čeprav gre za povsem drugačno razporeditev upodobljenih oseb. Sedaj gre za obraten "proces", in sicer za labodovo/moško izstopanje iz telesa. To telo pa je enako dvospolno, ker je podobno ptičji glavi, a je v njem mogoče prepoznati človeške oblike. Iz neznansko lepe Lede, ki je upodobljena erotično dražljivo, ker je viden del golih prsi, prihaja skozi usta in najbrž predstavlja posledico njene oploditve, ki se je v tem domišljijskem svetu morebiti zgodila. Dokaz je majhen labod, ki počiva na upodobljeni ženski glavi kot majhen modni klobuček. Ali pa je treba to kompozicijo pravilno brati brez vsega tega pripovednega balasta in bi nam morda Krašovčeva s svojo risbo želela povedati nekaj več o samih antičnih mitih in njihovih prisotnostih na delih likovne umetnosti. Ker namreč ti živijo le v človeškem miselnem in pripovednem svetu, morajo tudi njihovi odsevi na likovnih delih ostati del imaginarnega in sanjskega sveta.

falično dejanje (spolnost) zamenja s poezijo. In sta zato užitek in lastenje onkraj faličnega reda. /.../ Nikjer obscenosti telesa; ki se očiščeno zdaj "vrača«, dviga iz zemlje v nebo, da gledamo podobe raja, paradiža.« (1983, n. p.) Medved je tako označil tudi risbe v monografiji o slikarki leta 1994 z manjšimi popravki v besedilu $(1994,7-100)$. 


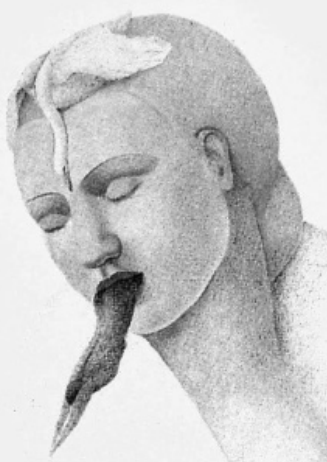

Slika 7: Metka Krašovec: Brez naslova, 1986 vir: Metka Krašovec, 1999, 47

Kljub izvirnemu koncipiranju kompozicije slikarke Metke Krašovec ševedno sledijo prekaljeni tradiciji, živi pogosto tudi v 20. stoletju, ki razmerje med Ledo in labodom razume kot podobo para, moškega in ženske. Šele 19. stoletje je namreč izoblikovalo vsebinske poudarke njunega odnosa; ta začne kazati na nepremostljive razlike, ki bodo nedvomno zanimive za mlajše ustvarjalce. Pomemben segment upodobitev v 20. stoletju ${ }^{29}$ predstavljajo poetične oziroma lirizirane predstavitve motiva, ki vsebujejo posebne ženstvene detajle, ker so dejansko nastale izpod rok ženskih umetnic in jim lahko upravičeno pripišemo zasnovo feminističnih podtonov. Ob leta 1997 ustvarjeni Ledi $z$ labodom Marine Bahovec se vračamo k posebni kompoziciji Leda $z$ labodom iz leta 1923 in njeni avtorici Marie Laurencin. Kot poudarja Liz Hager, gre za prelomno umetnino v Ledini tradiciji, ker se z ženskim pogledom izoblikuje novo branje motiva (2010). Slikarkina kompozicija spominja na prizor iz živalskega vrta: Leda je sedaj času nastanka slike primerno oblečena modna dama, ki nežno boža laboda po vratu, med njima pa obstaja nepremostljiva simbolna daljava, ker sta ločena s tanko črno ograjo. Celotni vtis slike je primerljiv z nežno kompozicijo rožnatih odtenkov slikarke Marine Bahovec, ki jo odlikujeta »barvna kultiviranost s pridihom Matissovega ornamenta« in posebej gracilna drža tudi tokrat oblečene Lede, ${ }^{30}$ ki ji je krhki labod pridan le kot

29 Za pregled motiva v 20. stoletju priporočam članek Regine Hackett, ki kljub besedilni skromnosti postreže z odličnim naborom likovnih del (2010).

30 Feministično branje se vsiljuje pri odlični sliki Marka Jakšeta Leda (1990) in je morda povsem 
poetična kulisa in ne kot zanesljivi nosilec izvirnih pomenov antičnega vira (Komelj, 2010). Zgledu Bahovčeve je mogoče slediti pri vseh tistih kompozicijah, ki Ledo še zmeraj predstavljajo kot ženski akt, a je sedaj zasnovan tako, da ne prebuja erotičnih dražljajev, ampak nastopa le kot nevtralen znak, ki se ob labodu pojavi z namenom potrditve pripadnosti določeni ikonografski klasifikaciji. Erotični stik je brez dvoumnih namigov onemogočen na krhkih umetninah Karla Zelenka in Vladimirja Makuca. Zelenko je antično snov ovekovečil na krožniku s podglazurno poslikavo. Njegovo Ledo z labodom (1964) odlikuje »tekoča linija«, značilna risba, »ki nosi v sebi sledove študija starih mojstrov, od Rembrandta do Ensorja« (Čadež Lapajne, Lorenčak, Simšič, 2004, 14; Sedej, 1978, 3-7). Umirjeno zastavljena dvojica ženskega akta in laboda sporoča za Zelenka tipični intimizem (Karel Zelenko, 1998, 15). Tako kot pri Maxu Ernstu, ki je svoj ustvarjalni opus poselil z najrazličnejšimi vrstami ptic, nas motiv Lede pri Makucu prav tako ne preseneti. Pri umetnini Leda I (2000) je labod prevzel značilno statično pozo Makučevih ptic, zraven njega pa ležerno počiva mitska žena na po srednjeveško ${ }^{31}$ zasnovanem otočku. Družbo jima delajo »črke, številke« in drugi znaki, ki jih je umetnik sprejel s počečkanih ploskev cerkvenih sten (Zgonik, 2006, 3-19). Do kakršnega koli telesnega prepleta ne bo prišlo, Leda bo ohranila svoje dostojanstvo neokrnjeno, ostala bo plemenita "svetovljanka«, tudi labod bo ostal le ptica (Zgonik, 2006, 3-19).

Drugi pomemben segment predstavljajo likovna dela, ki v antično zgodbo na vsebinski in oblikovni liniji interpolirajo s prisotnostjo humorja in razmerje med obema glavnima junakoma razumejo izključno v podobi odnosa med človekom in živaljo. Nemalokrat so humorno zasnovani prav prizori erotičnega odnosa, ki se v tovrstnih kompozicijah izkaže za nenaravnega in nenavadnega. Fotograf Helmut Newton je na odlični fotografiji (2005) dogajanje antičnega mita postavil v sodobno

upravičeno, če upoštevamo, da so se slikarja zmeraj "najpogumneje lotile emancipirane filozofinje s stališča psihoanalize /.../, saj so vzele v varstvo gejevsko izraznost in svobodoljubnost « ter dejstvo, da se je slikar sam imenoval za »ženo NSK-ja (Kostić, 1999, 17; Starc, 2000, 38-44) (Pod NSK je v izvornem besedilu mišljeno Neue Slowenische Kunst.) Jakšetova mitska ženska je upodobljena s skrotovičenimi udi, s katerimi se vztrajno bori s kar tremi labodi, ki so jo dejansko neusmiljeno napadli. Ker se labodji vratovi nepopustljivo prepletajo z njenimi telesnimi deli, ima gledalec občutek, da so pošastno učinkujoče ptice prodrle tudi že pod njeno oblačilo. Eno labodjo glavo je Leda že pokončala, ker negibno leži v vodi, drugi dve drži s krvavimi prijemi. Če gre pri vsebini slike za erotične poudarke, so ti zagotovo homoseksualni, ker so labodji vratovi Ledo napadli od zadaj in bi pri Jakšetu, ki ne pozna avtocenzure, pričakovali upodobljene analne erotične namige. Če pa je slikar želel predstaviti Ledo kot neuklonljivo bojevnico, ki bo s krvavo borbo preprečila polastitev svojega telesa, mu je to s prepričljivo postavitvijo prizora v skrivnostno pokrajino $\mathrm{z}$ vodo in dinamično kompozicijo brezkompromisne figuralike zagotovo odlično uspelo. Jakšetu je mogoče še pri eni sliki pripisati ukvarjanje $\mathrm{z}$ antično zgodbo, kakšno desetletje mlajša Jakšetova slika Si me zaklal, se posral in zbežal ... (iz cikla Serije in omaži) je morda celo nastala kot avtorjev spomin na Ledo iz leta 1990. Na njej je upodobljen moški anus, ob njem čisto pravo človeško »sranje« in nad njim pet labodjih glav, ki bi se jih dalo razložiti v kontekstu Ledine zgodbe.

31 Mišljena je navezava na poznogotske freske, ki so Makucu zelo blizu: »Preučevanje in kopiranje poznogotskih fresk sta $\mathrm{v}$ njegovo ustvarjanje vnesla tako formalne lastnosti gotskega slikarstva kot njihovo pričevalnost o estetskih nazorih prostora« (Vignjević, 2002, 22-29). 
opremljeno dekliško sobo na sredo postelje. Ledo tokrat predstavlja atraktivna vrhunska manekenka (Nadja Auerman), laboda pa nagačeni nadomestek. Prizor s pernato protezo, ki jo lepotica pritiska k sebi v delu mednožja, bo pred senzualnimi vtisi pustil občutek izumetničenosti. ${ }^{32}$ Tudi slikar Rudi Španzel je v svojem pogledu na motiv Lede izpustil značilno kuliso rečnega brega in mitološko zgodbo preselil na parket pred odprto okno v ljubljanskem stanovanju. Čeprav je slikar nemalokrat doživel odklonilen odnos občinstva do svojih slikarskih kompozicij, ki mu velikokrat ni bilo naklonjeno ${ }^{33}$ brez prisotnosti globljega razmisleka, se je velikokrat izkazal pri razkazovanju izvirnih ikonografskih metamorfoz. Na številnih slikah se Španzel zelo uspešno »poigrava z ikonografijo«, največkrat z duhovito ${ }^{34}$ osebno vživetostjo (Poštrak, 2004, 12). Njegova slika Leda $z$ labodom (1972) je na videz preprosta kompozicija, ${ }^{35}$ sestavljena iz statičnega kipa in nad njim letečega laboda, a skriva v sebi zapleteno zmes mnogih slikarjevih idej in zamisli. Poleg tipičnega slikarjevega »trompe l’oeila«, ki so ga mnogi zmeraj občudovali, ${ }^{36}$ in simetrične kompozicije, razgibane $z$ labodjimi krili, pri kompoziciji zaslutimo posebno težnjo po hotenem odmiku od realističnega $\mathrm{k}$ transcendentalnemu, kar bi bila lahko posledica slikarjeve izrazite predanosti baročni umetnosti. Sama po sebi se vsiljuje primerjava s fotografsko kompozicijo Aria (1963) Giulia Paolina, ki ima s Španzlovo Ledo veliko skupnega. Tudi tu gre za izpraznjeno sobo in kiparsko oblikovani ženski akt z domišljijsko dodanimi krili, ki pa tokrat v celoti lebdi v zraku in je baročno občutena težnja po irealnem toliko bolj izpostavljena (Cooke, 1989, 449-450).

32 Fotografijo so v "portfoliu « reproducirali v reviji Photo. V njem so zbrali nekaj fotografij na temo človeka v odnosu do ptic, s čimer so želeli komentirati aktualno perečo problematiko ptičje gripe (Tobin, 2006, 48-55).

33 Neprizanesljiva likovna kritika mu je velikokrat očitala preveliko zazrtost v slikarsko preteklost in neprimernost oziroma nezmožnost razbiranja določenih vsebinskih sporočil (Komelj, 2009, 25-45).

34 Na bogastvo Španzlovih ikonografskih domislic je doslej najizraziteje opozoril Lev Menaše (2009, 12).

35 V vseh detajlih je Španzlovo Ledo z labodom navdušeno predstavil Igor Zidić: »Tudi svojo Ledo /.../ je našel v Louvru - tam je bila Dedalsesova Venera /.../ Tej Ledi ni vzel zgolj mitske, ampak tudi muzejsko dimenzijo; $s$ tem je spremenil njen duhovni in predmetni pomen. $Z$ enako svobodo ravna tudi z ikonografskim stereotipom. Ta tema že od antičnih časov predpostavlja prizor posilstva, $\mathrm{v}$ katerem si zakrinkani Zevs jemlje poželeno žensko. Španzel zanika napetost, taji konfrontacijo dveh bitij v boju-objemu, obide igro zapeljevanja-nadlegovanja, ne pokaže trenutka »napada«. Njegov labod je priletel skoz okno in pristal na ramah kamnite lepotice kot gosak vrh plota. Med Ledo in labodom se - prvikrat - ne dogaja nič, nič pa se tudi ne bo zgodilo. Iz različnih snovi sta (iz mesa in kamna), v dveh agregatnih stanjih: zato ta labod sploh ne ve, da je na Ledi. Njegova razpeta krila nad rameni antičnega torza pa so vendar učinkovita, saj oblikujejo besedno igro: Ledo preobražajo v Nike. /.../ Ta paradoks Venere, ki je - preoblečena s tujo pomočjo, maskirana s samo labodovo bližino - nehala biti Venera in je postala Leda, se pravi paradoks Lede, o kateri vemo, da je (vendarle) Venera, in laboda, o katerem vemo, da ni Zevs (ker ga ne vodi strast, ker mu ob imenu Leda nič ne pride na misel), in nazadnje, asociirane Nike, ki postaja Zmaga, ki je omahnila - vse to kaže, koliko je slojev v eni (dobri) domislici. Tu nastaja circulus vitiosus, čarovnija neizrabnosti igre, zakaj Nike (Zmaga), ki je ženska, lahko podleže zgolj kot Venera - zato je tudi brez peplosa! - Venera, ki se skloni pod labodovo težo, pa bi utegnila biti tudi Leda. Zares dobro premešano!« (1983, 40-59)

36 Španzlovo odkrito »ljubezen « do starih mojstrov je večkrat natančno predstavil Luc Menaše (Smrekar, Menaše, Breščak, 2001, 14-15). 


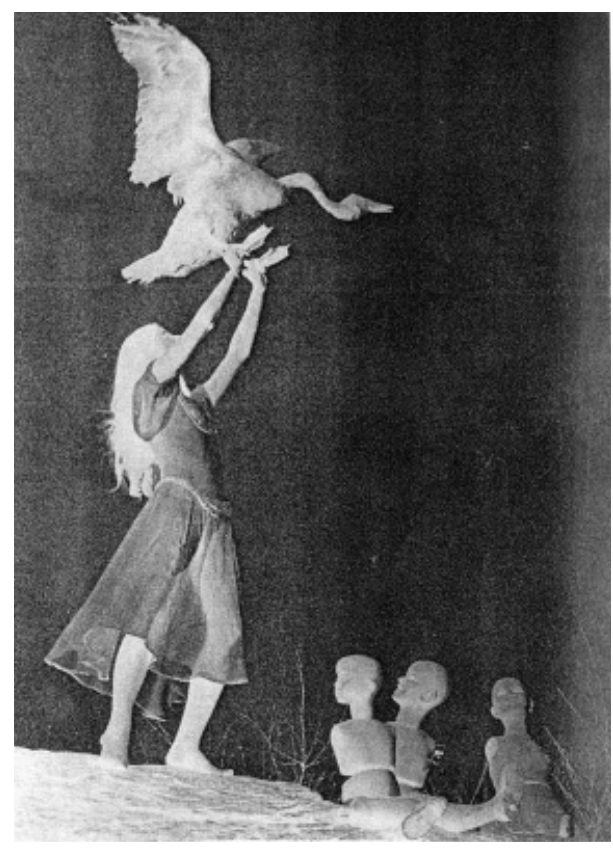

Slika 8: Stane Jagodič: Hrepenenje, 1972 vir: Stane Jagodič, 2008, n. p.

\section{Sklepne misli}

Pomembnost motiva Lede $\mathrm{z}$ labodom potrjuje obstoj trdožive evropske tradicije od antike do 20. stoletja, ki se ji vzporedno zrcalijo slovenske umetnine od klasicizma do poznih devetdesetih let prejšnjega stoletja. Do 19. stoletja se vzpostavlja predvidljivi niz z izključno erotičnimi značilnostmi prepojenih umetnin, ki so si kljub slogovnim posebnostim zelo sorodne tudi po zasnovi likovnih kompozicij. Premočrtno potekajoči upodabljajoči kliše se v tem času začne rahljati in se docela spremeni z ustvarjalci 20. stoletja. Z njimi doživi motiv Lede z labodom korenite spremembe, ker ne nastopa več samo kot podoba zaljubljenega para, ampak postane razmerje med človekom in živaljo problematizirano $\mathrm{z}$ ambivalentnimi konotacijami. Če je do sedaj narekoval vsebinsko in oblikovno zasnovo likovne kompozicije naročnik ali širši okus občinstva, ki si je pogosto zaželelo le dosledno ilustriranje antičnega vira, se sedaj umetnina izoblikuje kot posledica svobodne izbire umetnika, ki si motiv prisvoji iz različnih razlogov. Šele $z$ odgovorno osebno vživetostjo in samosvojim artikuliranim likovnim jezikom se izvorna vsebina primerno predrugači v skladu z umetnikovimi idejami in cilji. Če nekateri umetniki še sledijo prikazu erotičnih strasti, se pri večini drugih izoblikuje bogat izvirni prostor številnih vsebinskih premis. 


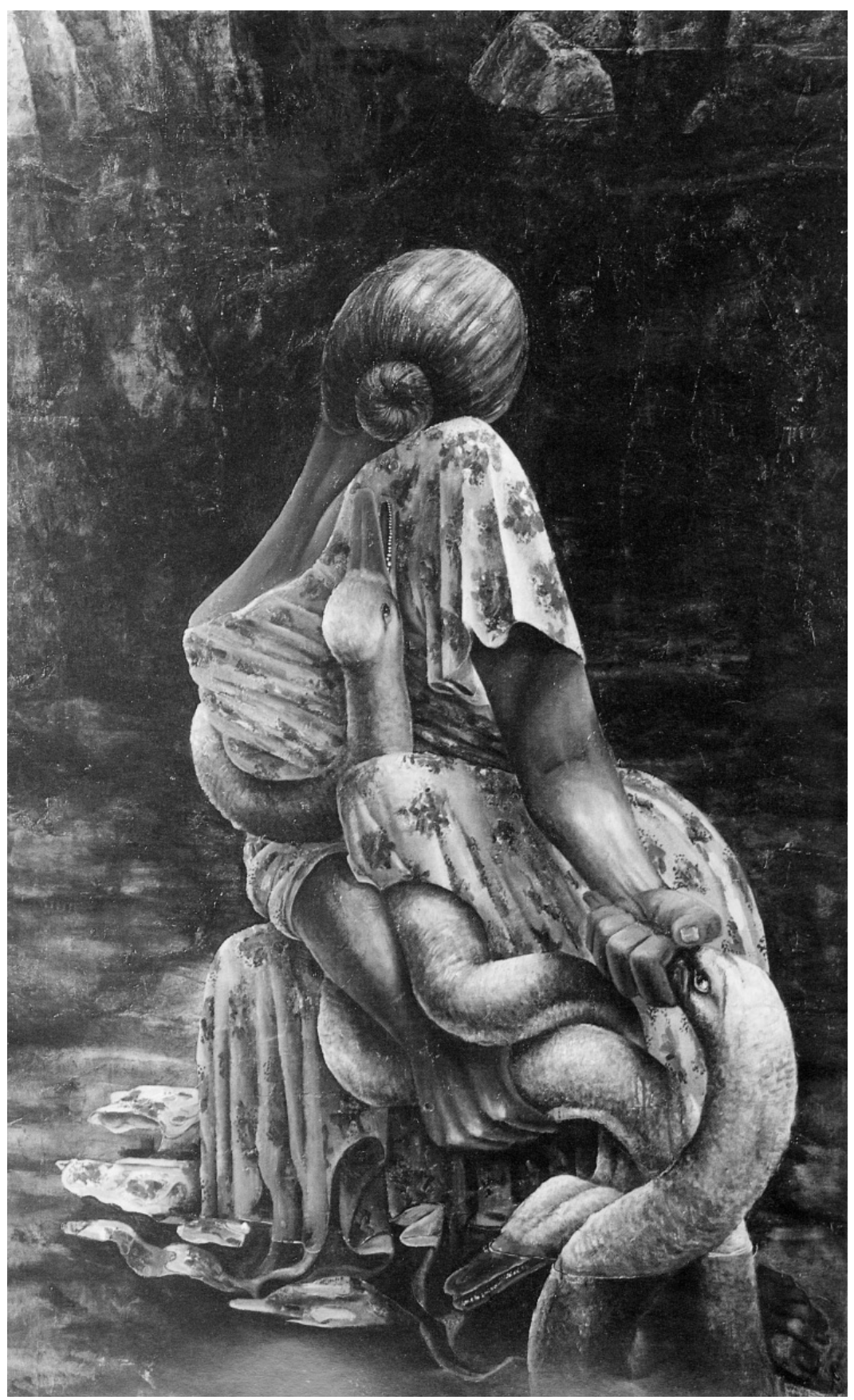

Slika 9: Marko Jakše: Leda, 1990

vir: Marko Jakše, 1995, n. p. 


\section{Literatura}

Ambrozić, K., Anton Ažbe umetnik (1862-1905), v: Wege zur Moderne und die Ažbe Schule in München. Pota $k$ Moderni in Ažbetova šola v Münchnu (ur. Ambrozić, K.), Wiesbaden-Ljubljana, 1988/89, 167-184.

Anfam, D., Cy Twombly, The Burlington Magazine (ur. Stone, R.), 150/1267, 2008, 701-702.

Animaux d'art et d'histoire. Bestiaire des collections genevoises, Ženeva, 2000.

Aubelj, B., Antična mitologija, Ljubljana, 2006.

Bizilj, P., Ženski akt prve slikarske generacije na Slovenskem, neobj. diplomsko delo (mentor Komelj, M.), Oddelek za umetnostno zgodovino, Filozofska fakulteta, Ljubljana, 2007.

Chevalier, J. in drugi, Slovar simbolov, Ljubljana, 1995.

Cooke, L., Giulio Paolini, The Burlington Magazine (ur. Elam, C.), 131/1035, 1989, $449-450$.

Čadež Lapajne, D., Lorenčak, M. in Simšič, M. (ur.), Keramika v Sloveniji (1964-2004). Keramika od 1964 do danes, Ljubljana, 2004.

Dali (ur. Ades, D.), Benetke, 2004.

Dolenc, A., Harfa v molu, Ljubljana, 2009.

Geniji v umetnosti. Leonardo (ur. Trenc-Frelih, I.), Ljubljana, 1990.

Germ, T., Simbolika živali, Ljubljana, 2006.

Germ, T., Podobe antičnih bogov v likovni umetnosti od antike do izteka baroka, Ljubljana, 2001.

Globočnik, D., Ledina igra, v: Jože Meglič (1939-2006), Šmartno pri Litiji, 2009.

Grobler, A., Pogled. Dotik. Objem, v: Metka Krašovec (ur. Grobler, A.), Ribnica, 2010.

Hackett, R., Leda now, still with Swan, http://www.artsjournal.com/anotherb/2009/10/ leda-now-still-with-swan.html/ [6. 5. 2010].

Hager, L., »Swan's Way«: The Many seductions of Leda, http://venetianred.net/swansway-the-many-seductions-of-leda.html $[$ [1. 6. 2010].

Hall, J., Dictionary of Subjects and Symbols in Art, London, 1974.

Hopkins, D., Max Ernst's »La toilette de la mariée«, The Burlington Magazine (ur. Elam, C.), 133/1057, 1991, 237-244.

Stane Jagodič. Zoo Poetika, Ljubljana, 2008.

Marko Jakše, Ljubljana, 1995.

Knauer R., E., Leda, Jahrbuch der Berliner Museen, 11, 1969, 5-35. 
Komelj, M., Izrekanje ljubezni v italijanski umetnosti od Staufovskega časa do črne smrti, neobj. magistrsko delo (mentor Golob, N.), Oddelek za umetnostno zgodovino, Filozofska fakulteta, Ljubljana, 1999.

Komelj, M., Traktat o gorečem križu, Likovne besede (ur. Brumen-Čop, A. in Zlokarnik, M.), 61, 62, Ljubljana, 2002, 118-125.

Komelj, M., Angelska prisotnost v umetnosti Metke Krašovec, v: Metka Krašovec, Ljubljana, 1995.

Komelj, M., Svetniki. Slikarstvo XVIII. stoletja na Slovenskem, Ljubljana, 2008.

Komelj, M., Opažanja s kritiške poti, Forum (ur. Gorupič, B.), II/3, 4, Ljubljana, 2009, 25-45.

Kos, M., Predmeti na Tominčevih portretih, v: Jožef Tominc. Fiziognomija slike (ur. Jaki, B. in Breščak, M.), Ljubljana, 2002, 33-36.

Kostić, A., Ekološki slikar reciklirajoče zavesti, Večer, Maribor, 1999.

Kranjc, I., France Kralj. Dela iz javnih in privatnih zbirk, neobj. magistrsko delo (mentor Šumi, N.), Oddelek za umetnostno zgodovino, Filozofska fakulteta, Ljubljana, 1993.

Kržišnik, Z., Vstopanje v skrivnost umetniške prakse Metke Krašovec, v: Metka Krašovec. Pregledna razstava grafik in risb (ur. Soklič, B.), Ljubljana, 1999, 6-8.

Maković, Z., Ferdinand Kulmer, v: Ferdinand Kulmer (ur. Medved, A.), LjubljanaPiran, 1989.

Mastnak, T., Profana ikonografija baročnega stenskega slikarstva na Slovenskem, neobj. diplomsko delo (mentor Šumi, N.), Oddelek za umetnostno zgodovino, Filozofska fakulteta, Ljubljana, 1986.

Mastnak, T., Od poparta do neoplatonizma, v: Metka Krašovec. Pregledna razstava grafik in risb (ur. Soklič, B.), Ljubljana, 1999, 12-20.

Matijevič, J., Onkraj, v: Samo Kralj, Novo mesto, 2007, 5-6.

Medved, A., O luči in temi, o igri in spominu, o zemlji in nebesih v slikarstvu Metke Krašovec 78-83, v: Metka Krašovec, Ljubljana, 1983.

Medved, A., Slika kot psihična podoba, v: Metka Krašovec (ur. Habič Pregl, B.), Ljubljana, 1994, 7-100.

Menaše, L., Marijanska ikonografija v slovenskem slikarstvu od začetkov do prve svetovne vojne, neobj. diplomsko delo, Oddelek za umetnostno zgodovino, Filozofska fakulteta, Ljubljana, 1974.

Menaše, L., Akt na Slovenskem. I. slikarstvo, Ljubljana, 1999.

Menaše, L., Akt na Slovenskem. II. kiparstvo, Ljubljana, 2000. 
Menaše, L., Umetnost Rudija Španzla, Ljubljana (ur. Šumi, N.), XIV/5, 6, Ljubljana, 2009.

Hochstetler Meyer, B., Leonardo's Hypothetical Painting of »Leda and the Swan«, Mitteilungen des Kunsthistorischen Institutes in Florenz, 34/3, 1990, 279-294.

Mikuž, J., Nema zgovornost podobe, Ljubljana, 1995.

Naso, P. O., Metamorfoze, Ljubljana, 1977.

Neret, G. in drugi, Erotik in der Kunst des 20. Jahrhunderts, Köln, 1993.

Novak A., B. in drugi, Zarja časa. Mit v sliki in besedi, Ljubljana, 1997.

Osvald, M., Dionizična ikonografija v Pompejanskem slikarstvu, neobj. diplomsko delo (mentor Menaše, L.), Oddelek za umetnostno zgodovino, Filozofska fakulteta, Ljubljana, 1997.

Oven, M., Pomeni ptic v francoskem simbolističnem slikarstvu, neobj. diplomsko delo (mentor Menaše, L.), Oddelek za umetnostno zgodovino, Filozofska fakulteta, Ljubljana, 2000.

Pelko, T., Hraniteljeve kreacije za dobrodelne namene, Dobro jutro, 8/219, Ljubljana, 2009.

Poštrak, P., Umetnost Rudija Španzla, neobj. diplomsko delo (mentor Komelj, M.), Oddelek za umetnostno zgodovino, Filozofska fakulteta, Ljubljana, 2004.

Prša, D., France Mihelič, neobj. proseminarska naloga (mentor Komelj, M.), Oddelek za umetnostno zgodovino, Filozofska fakulteta, Ljubljana, 2000.

Salecl, R., Love me, Love my Dog: Psychoanalysis and the Animal/Human Divide, v: Interpol. The Art Show Which Divided East and West (ur. Čufer, E. in Misiano, V.), Ljubljana, 2000, 111-121.

Sedej, I., Grafika Karla Zelenka, v: Karel Zelenko/Grafike, Ljubljana, 1978, 3-7.

Sedej, I., Ljubezen v stotih slikah, Ljubljana, 1993.

Simončič, A., Antični motivi v slovenski likovni umetnosti, neobj. diplomsko delo (mentor Komelj, M.), Oddelek za umetnostno zgodovino, Filozofska fakulteta, Ljubljana, 2000.

Smrekar, A., Menaše, L. in Breščak, M. (ur.), Luc Menaše. Zapisi 1951-1994, Ljubljana, 2001.

Soklič, B., Pot v notranjost, v: Metka Krašovec. Pregledna razstava grafik in risb (ur. Soklič, B.), Ljubljana, 1999, 9-11.

Stallabrass, J., Sodobna umetnost. Zelo kratek uvod, Ljubljana, 2007.

Starc, A., Marko Jakše. Mitologizacija in mitizacija, neobj. diplomsko delo (mentor Komelj, M.), Oddelek za umetnostno zgodovino, Filozofska fakulteta, Ljubljana, 2000. 
Tobin, J., Le poulailler des photographes. Tentative d'inoculation du virus de l'humour du talent!, Photo (ur. Colmet Daage, E.), 428, Pariz, 2006, 48-55.

Jožef Tominc (1790-1866), Ljubljana, 1967.

Touch me/Abstract Eroticism, v: ArtङDesign (ur. Kearton, N.), 11/3, 4, London, 1996.

Vignjević, T., Podoba in abstrakcija. Abstraktna oblika in specifika prostora $\mathrm{v}$ ustvarjanju Vladimirja Makuca, v: Vladimir Makuc, Ljubljana, 2002, 22-29.

Widauer, H., Willinger, B. in Willinger, U. (ur.), Peter Paul Rubens, Dunaj, 2004.

Zarnik, M., Slovenski slikarji v Monakovem, Ljubljanski zvon, 20, 1900, 167-168.

Karel Zelenko/Sto grafičnih listov (1955-1995), Ljubljana, 1998.

Zgonik, N., Vladimir Makuc v osišču časov, prostorov in tradicij, v: Vladimir Makuc. Dela, Ajdovščina, 2006, 3-19.

Zidić, I., Španzel, eksorcist, v: Rudi Španzel (ur. Kraševec, V.), Ljubljana, 1983, 40-59.

Žerovc, B., Simbolizem v slovenskem slikarstvu (1890-1918), neobj. diplomsko delo (mentor Komelj, M.), Oddelek za umetnostno zgodovino, Filozofska fakulteta, Ljubljana, 1997.

Župančič, O., Podaj mi roko, pesem (ur. Mahnič, J.), Ljubljana, 2000.

\section{Elektronski viri}

http://www.prireditve.org/razstave/slike-marine-bahovec/, besedilo: Komelj, M. [5. 5. 2010]. 


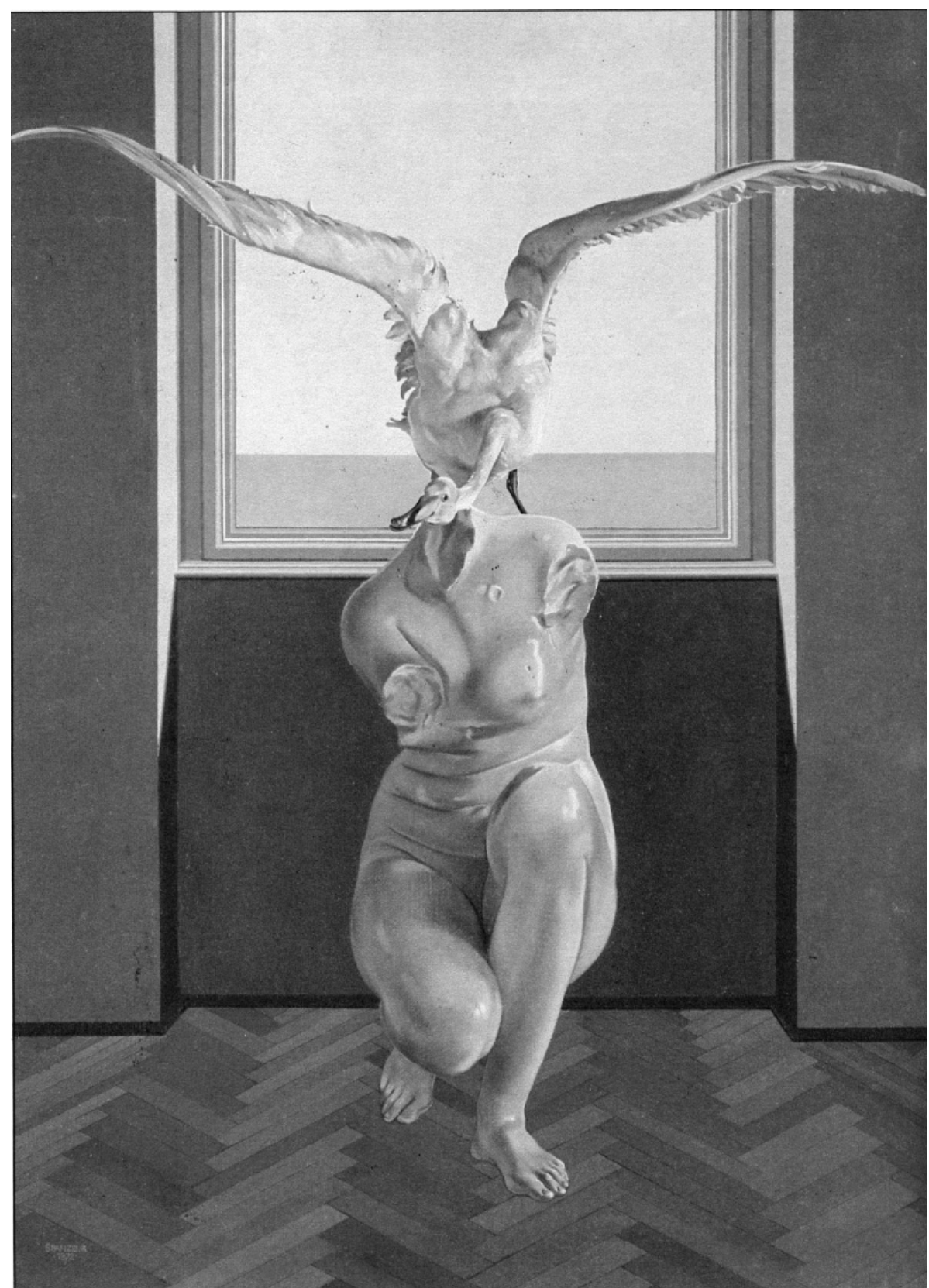

Slika 10: Rudi Španzel: Leda $z$ labodom, 1972 vir: Rudi Španzel, 1983, 68 
Dejan Prša

\section{The Lover with a Long Neck: The Motif of Leda and the Swan in Twentieth-Century Slovenian Painting}

Keywords: swan, Leda, twentieth-century Slovenian painting, iconography, zoophilia, interpretations

This article presents the thesis that the motif of Leda and the Swan, which had a remarkable impact on the arts in the modern era (especially in the period between the Renaissance and the end of the twentieth century), represents one of the most significant Ancient motifs in twentieth-century Slovenian painting. Comparing works of fine arts with European models, comparative research on Slovenian artists' works, and motif analysis disclose reasons for its popularity in Slovenian ethnic territory and reveal both the stereotyped and original content and the messages incorporated into the motif. Not only have some of the most eminent figures in Slovenian painting (e.g., Jožef Tominc, Anton Ažbe, France Kralj, Stojan Batič, Metka Krašovec, Rudi Španzel, and Marko Jakše) dedicated themselves to the motif, but the creations of numerous lesser-known artists (e.g., Samo Kralj, Jože Meglič, and Marina Bahovec) have also been particularly influenced by the motif of Leda and the Swan. 